DOI: 10.1515/ausp-2015-0060

\title{
Born or Made? An Overview of the Social Status and Professional Training of Hungarian Interpreters in Romania
}

\author{
Noémi FAZAKAS \\ Department of Applied Linguistics, \\ Faculty of Technical and Human Sciences, Târgu Mureş \\ Sapientia Hungarian University of Transylvania \\ galfnoemi@gmail.com \\ Krisztina SÁROSI-MÁRDIROSZ \\ Department of Applied Linguistics, \\ Faculty of Technical and Human Sciences, Târgu Mureş \\ Sapientia Hungarian University of Transylvania \\ sarosikrisztina2015@gmail.com
}

\begin{abstract}
There is a recurrent debate in the scholarly literature on interpreting studies: are interpreters made or born? While classical interpreting schools state that great interpreters are born and that formation and development is of a secondary importance, the newest publications on this topic place a much greater stress on the formation and development of interpreting abilities, skills, and competences. The latest results also challenge several ideas and stereotypes concerning the personality and attitudes of interpreters. This article outlines the position and situation regarding Hungarian interpreters in Romania with a special regard to the legal framework, and to the present state of professional training. The study also discusses why interpreters of Hungarian are much more likely to be born in Romania, and not made, (a factor that hinders the professionalization of Hungarian interpreters in Romania). Equally significant are the legislative loopholes which enable untrained individuals to perform interpreting activities (even economic activities), the result of which is a significantly poorer image of the profession, and a lowering of the quality of work it produces. We also give a short overview of the translation and interpreting programmes. As the majority of the Hungarian population in Romania reside in Transylvania, we confine our overview to Transylvanian universities.
\end{abstract}

Keywords: translation and interpreting studies, Romanian legal framework, minority languages and translation, interpreting, translation and interpreting training in Romania 


\section{Are interpreters born or made? Short overview of the literature}

Interpretation is regarded as a special form of translation, preceding written translation and in fact writing itself (see Pöchhacker 2004: 9). Although interpreting is usually defined as oral translation, this does not include all types of interpreting, for example sign interpreting. The experts suggest that the most important viewpoint in distinguishing translation from interpretation is its immediacy, as the source-language text (written, oral, or signed) is transmitted "here and now" (vid. Pöchhacker 2004: 10). Another important differentiation criterion is the availability of the source text: while the translator has the source text available in some fixed form, allowing him/her to refer back to it, an interpreter gets only one attempt at producing the target text (Kade qtd by Schäffner 2004: 1).

The debate regarding nature or nurture has been long present in the scholarly literature, as several scholars and researchers hold different views on the skills needed by interpreters in performing their task. The literature features two main models regarding (mainly conference) interpreters: "the acquired-skills model as opposed to the inborn-abilities model” (Kopczyński-Kowaluk 1997: 2075). Most scholars consider these two models to be mutually exclusive.

One of the most important representatives of the born-not-made school of thought was Nida, while Healey supported the made-not-born approach (Gile 2009: 7). Popular thought and - as our study presented below also shows - even that of translators and interpreters is more in favour of the inborn-abilities model: an interpreter is first and foremost born to be an interpreter, with personality traits such as extroversion, good social skills, sometimes an exhibitionist, selfconfidence, outstanding memory skills, quick reaction time, good concentration abilities, good presenting skills, etc. (Válóczi 2010: 29).

The professionalization of interpreting brought about a shift in perspective regarding the need for training, and the latest literature on interpreting includes publications and studies supporting the made-not-born approach.

For example, the results of Kopczyński and Kowaluk's 1997 article show that "trained interpreters have mastered some strategies which allow them to deal with the task more satisfactorily compared to untrained bilinguals" (KopczyńskiKowaluk 1997: 2082), and these are consistent with the criteria of the acquiredskills model. However, they conclude that interpretation talent does exist, as "some people are more gifted than others" (Kopczyński-Kowaluk 1997: 2083).

The website of the International Association of Conference Interpreters features the following answer to our question:

It takes training, practice, a professional attitude, and enough determination to stay the course for a career as a professional interpreter. Acquaintance with many foreign languages and cultures is simply not enough. Before you can begin to 
work as a professional, you must master interpretation methods and techniques by attending an appropriate university-level course. You do not necessarily have to be brought up speaking many languages to become an interpreter. Nowadays, most of those who become interpreters have acquired their foreign languages, but to a very high level of proficiency. ${ }^{1}$

In his 2009 book on interpreter and translator training, Gile concludes that "while certain 'natural' aptitudes are prerequisites to high-quality translation - especially literary translation - or to simultaneous interpreting, it makes little sense to challenge the idea that guidance into Translation can be useful, be it for the purpose of helping natural talents unfold and develop or for instruction in technical procedures (...) and in the acquisition of linguistic and extralinguistic knowledge" (Gile 2009: 7).

Gile also states that while formal training is not mandatory for would-be translators in the $21^{\text {st }}$ century, it can perform at least two very important functions: on the one hand, formal training can help individuals wishing to become professional translators or interpreters "enhance their performance to the full realization of their potential," while, on the other hand, it can provide a more rapid acquisition of skills than through field experience and self-instruction (Gile 2009: 7).

In the following, we present the status of Hungarian translators and interpreters in Romania, the legal framework, a number of training programmes as well as the results of a survey conducted among Hungarian translators and interpreters working in Romania regarding their views and opinions on the most important problems and issues of the profession in this context.

\section{The status of the Hungarian sworn translators and interpreters in Romania}

\subsection{Translation and interpretation: lack of professional differentiation}

Before attempting a detailed discussion of the legislation regarding sworn translators and interpreters, it is important to stress that authorization bodies do not acknowledge the underlying differences between the two occupations or professions (vid. Greere-Tătaru 2008, Greere 2010). In the following, I aim to present the scale of diversification of the two professions in a bottom-up sense: first, I deal with the classification of occupations, then with the nomenclature of economic activities, and finally with the legislation in force.

Romanian market practices show an awareness of the fact that "translation and interpreting are two different professions, entailing two distinct sets of competences and being performed by different specifically trained individuals" (Greere 2010: 792). Accordingly, the 2014 Classification of Occupations in Romania

1 http://aiic.net/p/1669\#Q5 (last accessed on April 21, 2014). 
includes several occupations in interpreting and translation. These occupations form two conceptual groups from the point of view of our research: one represents the different interpretation activities: 264302 - Interpret ('interpret'), 226602 - Interpret în limbaj mimico-gestual - studii medii ('sign language interpreter - secondary education'), 235202 - Interpret în limbaj mimico-gestual - studii superioare ('sign language interpreter - university degree'), 264303 - Interpret relații diplomatice ('interpreter in diplomatic relations'), while the other group includes translation-related occupations: 343517 - Traducător - studii medii ('translator - secondary education'), 264306 - Traducător - studii superioare ('translator - university degree'), and 264307 - Translator ('translator'). ${ }^{2}$

The nomenclature of economic activities (the statistical classification of economic activities) in Romania differentiates the two types of activities (written and oral translation, where interpreting is conceptualized as the latter), and the two activities receive one NACE code (7430 - Activități de traducere scrisă şi orală (interpreți) 'written and oral (interpreting) translation activities'). ${ }^{3}$

Legal stipulations also address the two professions as one: Law 178/1997 regarding the activity of translators and interpreters, employed by "legal authorities including the Ministry of Justice, courts and tribunals, notary public offices and attorneys-at-law do not distinguish in any way between the two professions" (Greere 2010: 792), as throughout the text of the legal document 'and/or' is used between the word translator and interpreter.

\subsection{Legislation and authorization}

According to the present legal stipulations and procedures in Romania, there are two distinctive procedures in obtaining an official professional status for translators and interpreters.

The Ministry of Justice authorizes translators and interpreters to work for legal authorities: the Ministry, courts and tribunals, notary public offices, and attorneys-atlaw. This area of occupation suggests a need for specific translation and interpretation skills and competences; however - as discussed below -, in most situations, this is not the case. The Ministry of Justice also lists professional translators and interpreters adding up more than 36,600 authorized translators, including more than 1,400 translators and interpreters with Hungarian as (one of) their working language(s). ${ }^{4}$ It is important to mention that it is not known how many of them are active.

2 Although the occupations of traducător and translator are differentiated, there is no description whatsoever of their activities, and thus it is not clear why there is a need for this distinction.

3 http://coduricaen.info/definitie Activitati de traducere scrisa si orala (interpreti) 7430.html (Last accessed: 13 March 2014)

4 The list of authorized translators: http://www.just.ro/MinisterulJusti\%C8\%9Biei/ Listapersoanelorautorizate/Interpretisitraducatoriautorizati/tabid/129/Default.aspx (last accessed on 26 March 2014). 
According to the stipulations of Law 178/1997, translators and interpreters authorized by the Ministry of Justice must be available for the Superior Council of Magistracy, the Ministry of Justice, the High Court of Cassation and Justice, the Public Prosecution Service, the National Anticorruption Directorate, the criminal investigation authorities, the courts, notaries public, lawyers and bailiffs; thus, it can be stated that it is "focused on procedures that are applicable in contexts where authorized translators and interpreters are required for the linguistic transfer of communication instances with legal value” (Greere 2010: 794). The law also stipulates that the institutions and legal entities enumerated above can only employ translators and interpreters who are professionally prepared and have an authorization issued in their name by the Ministry of Justice. ${ }^{5}$

Authorization is issued based on an application file submitted to the Ministry of Justice (by dossier), after which the applicant is issued an authorization which covers translation and interpreting from and into the foreign language it was requested for. The conditions of request are discussed below.

The second procedure of obtaining a translation certificate is by a testing procedure organized by the Ministry of Culture for different domains and special languages. This is available for graduates of undergraduate non-language degrees, who wish to obtain their certification as translators.

As Greere (2010) states, authorization is considered by many an official professional recognition by Romanian authoritative bodies and by the society as a whole: there are several biases in Romania regarding translators, according to which "an authorization is the only indicator of quality and only the holder of such an authorization is a professional" (Greere 2010: 791). Such attitudes seem to determine all aspects of professional activity having a distinctive mark on the way lay people, other professionals, and those belonging to the profession see themselves.

In the following, I wish to discuss the authorization process as well as the consequences of this lax procedure, the questions implied by the law on authorized and sworn translators and interpreters belonging to national minorities (with a special regard to the Hungarian minority), the flaws present in the authorization procedure and the text of the law, the aspects of linguistic rights, language ideologies and (cultural) biases behind the authorization procedure as well as the status of the authorized translators and interpreters form the professional point of view.

\subsection{The process of authorization from the point of view of national minorities}

The conditions of issuing the authorization by the Ministry of Justice (besides the eligibility conditions regarding citizenship, capability of performance, the lack of

5 „Persoane atestate în profesie şi autorizate de Ministerul Justiției” (Art. 2, Law 178/1997). 
a criminal record, as well as the professional and social recognition) include the following criteria of attesting the language skills needed:

1. The applicant holds an undergraduate language degree (or equivalent) in a foreign language (Philology and Applied Modern Languages alike) for which (s) he requests authorization, or

2. The applicant holds an undergraduate degree (or equivalent) certifying that (s)he graduated from a university programme organized in the foreign language for which (s)he requests authorization, or

3. The applicant holds a certificate (or equivalent) which shows that (s)he is the graduate of a high school with tuition in a foreign language or in the language of the national minorities (a language for which (s)he requests authorization), or

4. The applicant holds a translation certificate issued by the Ministry of Culture in the legal domain, based on which (s)he is certified to translate from Romanian into a foreign language, and based on which (s)he requests authorization to translate from the foreign language into Romanian.

It is important to stress that if the above conditions are met, the authorization is automatically issued by the Ministry of Justice "without having tested or verified in any way the distinctive competences required" (Greere 2010: 792), except for the last situation; nevertheless, the testing procedure is conducted by the Ministry of Culture and not by the Ministry of Justice.

Based on the above, a major conclusion can be drawn vis-á-vis translators and interpreters authorized and working in Romania, with a special regard to those belonging to the national minorities: as applicants are only required to attest their foreign language skills (proving Romanian language skills are not mentioned, as it is not required at all), in the case of translation authorizations issued by the Ministry of Justice the $A$ language of every applicant is considered to be Romanian. It is no exaggeration to state that in the light of the legislature in force every person who wishes to become an authorized translator - or more importantly, from the point of view of our study, an authorized interpreter - is supposed to be a native speaker of Romanian, with the Romanian language as his/her mother tongue.

The same idea is supported by the fact that the authorizations include only the "foreign languages" they are issued for (in the case of an English-French translator in Romania, only the English and the French languages), Romanian being the "default language" of translations and interpreting activities. 


\subsection{Professionalization or not? Challenges and downsides}

\subsubsection{Romanian language teaching}

According to the $3^{\text {rd }}$ criterion above, anyone who has graduated from high school with tuition in any foreign language or in the language of a national minority can apply for an authorization of translation. As a result, several issues arise from the point of view of the Hungarian minority in Romania.

The Inter-Institutional Committee for Translation and Interpretation states that "The A language is one (native tongue or equivalent) which the interpreter masters perfectly, and into which he/she is capable of interpreting consecutively and simultaneously from all his/her B and C languages. In exceptional cases, an interpreter may have two A languages." ${ }^{6}$ Although many Hungarians living in Romania declare themselves to be balanced bilinguals, in a survey conducted in 2004, only $0.8 \%$ declared themselves speakers of Romanian at the mother-tongue level. ${ }^{7}$

Romanian language teaching for the national minorities is still a highly debated topic in Romania. It is a fact that in the case of the Hungarian majority regions the teaching of the Romanian language has proven to be ineffective (or even a failure), and this is supported by the poor results obtained at national tests. Consequently, it has been a heated debate whether to continue teaching it as a mother tongue - which has proven not to be useful and successful in the Romanian language acquisition of Hungarian minority pupils - or teach it as L2 or foreign language, which has stirred heated arguments among the Romanian majority.

Because of the failure of Romanian language teaching for Hungarian pupils in Romania, it is important to stress that very few of the Hungarian mother-tongue pupils who graduate from a high-school with tuition in the Hungarian language have the necessary language skills to perform translation and interpretation, let alone any special training, to be able to make a living from this activity. However, as Greere (2010) also states, "many language graduates ${ }^{8}$ will seek out the authorization whether they intend to become translators or not, transforming translation into a safety net rather than a profession" (Greere 2010: 793).

\subsubsection{Hungarian - national minority language or foreign language?}

Article 1 of Law 178/1997 stipulates that translators and interpreters in Romania translate from and into foreign languages (into Romanian and from Romanian - as a default). ${ }^{9}$ The question of linguistic rights arises again, as according to

6 http://europa.eu/interpretation/doc/lang profiles in demand.pdf (Last accessed on 26 March 2014).

7 On the bilingualism of Romanian Hungarians, see Horváth 2005.

8 And, in our case, graduates of high-schools with tuition in minority languages.

9 “...interpreți şi traducători pentru efectuarea traducerilor în şi din limbi străine” (Article 1 of Law 178/1997). 
the text of this particular law the languages of national minorities in Romania are conceptualized as foreign languages as well, which is not in harmony with several other legal documents. For example, Law 1/2005, the Law of National Education differentiates between three groups of languages when discussing possible tuition: the Romanian language, worldwide spoken languages, and national minority languages. ${ }^{10}$ This mirrors a completely different point of view and attitude: first and foremost, national minority languages are accepted as the mother tongue of the minority in question. However, the ideology behind Law 178/1997 considers Romanian to be the mother tongue of any Romanian citizen wishing to become authorized as a translator/interpreter, while the national minority languages are considered to be foreign languages.

This issue is of a paramount importance. For example, the regulation governing admissions and language classification of the International Association of Conference Interpreters states that the interpreters work into their native languages (their $A$ languages) in both modes of interpretation, simultaneous and consecutive. ${ }^{11}$ From this point of view, it is important for a Hungarian mothertongue interpreter to have Hungarian recognized as his/her mother-tongue, and not to be expected to perform high-quality interpreting into a language of which (s)he does not have a perfect command.

Besides the problems it raises regarding linguistic rights, this ideology has another consequence related to the quality of translation as well as the professional acceptance of the occupation: in many cases, Hungarian mother-tongue translators and interpreters lack the language skills to produce high-quality translation and interpreting into Romanian. As a consequence, their professional acceptance is problematic, regardless of the high-quality translations they may produce into their mother-tongue or the high command they have of other foreign languages.

One need not forget that the Ministry of Justice issues authorizations to employ translators and interpreters in legal procedures, which are carried out in the language of the state, and thus it must be accepted that the Romanian language skills are a prerequisite in translating and interpreting in the legal domain. However, the issues raised and discussed above serve to stress the fact that the current procedure, although it demands it, does not guarantee high-quality translation or interpreting in legal contexts. Amendments to this procedure are strongly called for, and one of them is the issue of attesting Romanian language skills.

10 http://www.utcluj.ro/media/documents/2013/10__LEGE_nr1_actualizata.pdf (last accessed on 28 March 2014).

11 http://aiic.net/page/49 (last accessed on 28 March 2014). 


\subsubsection{Tacit acceptance of the lack of specialized training}

The second important conclusion that arises from the above presented conditions (specifically condition number 3 ) is that any graduate, whether of a bilingual highschool or establishment offering tuition in the language of national minorities, can (if they hold a certificate) request authorization. This implies that there is no need for any specialized training in order to work for the Ministry of Justice or any other legal authorities in Romania as a translator or interpreter. It is important to stress from our perspective that whoever graduates from a high-school with tuition in Hungarian intending to become a Hungarian sworn translator and interpreter (as the Romanian language is the "default" language), and to perform translation and interpreting between Romanian and Hungarian, can do so, as in the light of the current legislation - there is no requirement to certify special knowledge, translation or interpreting skills, or even general linguistic abilities, (not to mention issues of special languages and terminologies).

This is, however, unacceptable from the point of view of the profession. In the latest literature on translation and in the professional practice, it is increasingly common to see translation and interpreting as a process not unlike that of preventive medical intervention, as the translator/interpreter needs to anticipate the factors potentially threatening correct interpretation and minimize them (vid. Blum-Kulka, qtd by Robin 2013: 61).

That is why Chesterman (2001) has proposed the introduction of the so-called Hieronymic Oath (similar to the Hippocratic Oath), which, on the one hand, would serve the recognition of the profession and would help distinguishing the professional (and sworn!) translators from amateurs, while, on the other hand, providing ethical guidelines for the profession. However, under the current regulations, none of the above seems to be important.

Criterion number 4 includes the conditions regarding legal translations (traducător pentru specialitatea ştiințe juridice); however, this refers only to the recognition and supplementation of the authorizations issued by the Ministry of Culture based on an exam in legal translation. It is of particular interest that, while the Ministry of Culture organizes translation exams in several professional languages (e.g. for arts, chemistry, medical language, physics, geography, IT, economics, sociology, etc.), the Ministry of Justice only recognizes the certificates issued for the legal professional language, not the others. This brings to the fore another inconsistency: while the graduation diploma acquired in the language of national minorities (where the level of acquisition of specialized languages is highly questionable) is accepted by the Ministry of Justice as the legal base for issuing translation certificates, the certificates of professional translation granted by the Romanian Ministry of Culture (based on exams frequently preceded by specialized languages, terminology, and special text editing training) are not recognized. 
Nevertheless, the responsibility of sworn translators and interpreters is great: in the case of certificates issued by the Ministry of Justice, the authorized persons as we have previously mentioned - need to be constantly available to the judicial bodies. Within 60 days of the issuing of the certificate, the translators/interpreters are required to register at the district court of their permanent residence, based on which registration the competent judicial authorities can apply for their services. If the translator/interpreter refuses to collaborate and to offer services twice within one year or if a customer notifies the Ministry of Justice in writing, calling in to question the translator's/interpreter's professional ability to fulfil the task, the Ministry has the power to withdraw the certificate under paragraph d) and e) of Article 6 of Law 178/1997.

\section{Professional training of (Hungarian) translators and interpreters in Romania with special regard to Transylvania}

\subsection{Faculties and institutions with departments for the training of translators and interpreters in Transylvania}

The training of translators and interpreters in Romania is organized in two different types of departments established at various faculties within several public and private universities: departments of applied modern languages and departments of translation and interpreting studies. According to Appendix No. 8 of the Government Resolution on the approval of fields of study and specializations/study programmes, the structure of higher education institutions for the academic year 2014/2015 and approval of titles conferred to undergraduate education graduates enrolled in the academic years 2011/2012, 2012/2013, and 2013/2014, the students graduating from applied modern languages programmes receive a bachelor's degree in Applied Modern Languages, while those graduating from translation and interpreting studies programmes receive a bachelor's degree in Philology. However, based on both of these degrees, an authorization can be issued by the Ministry of Justice.

As the aim of this study is to trace the difficulties the Hungarian translators and interpreters face in their process of professionalization, we do not deal with all Romanian universities that offer translator/interpreter training; we include only those faculties and institutions that have departments dedicated to the training of translators and interpreters in Transylvania, as the vast majority of the Hungarian population lives in this region of the country. ${ }^{12}$

12 We operate with the present day, wider meaning and definition of Transylvania, which also includes the historical regions of Crişana, Maramureş, and the Romanian part of Banat (see e.g. 
In the following, we include a list of institutions training translators and interpreters in departments and programmes of applied modern languages:

1. Babeş-Bolyai University, Cluj Napoca (public university) - Faculty of Letters - Department of Applied Modern Languages

2. Transilvania University of Braşov (public university) - The Faculty of Letters - Department of Theoretical and Applied Linguistics

3. The West University of Timişoara (public university) - Faculty of Letters, History and Theology

4. "Vasile Goldiş" Western University of Arad (private university) - The Faculty of Humanities, Political and Administrative Sciences

5. "Lucian Blaga” University, Sibiu (public university) - The Faculty of Letters and Arts

6. Petru Maior University of Târgu-Mureş (public university) - Faculty of Sciences and Letters

7. North University of Baia Mare (public university) - Faculty of Letters

8. Tibiscus University of Timişoara (private university) - The Faculty of Journalism, Communication and Modern Languages - the specialization is no longer available.

Faculties and institutions with specialist departments for the training of translators and interpreters in Transylvania, within Departments of Translation and Interpreting Studies:

1. "1 Decembrie 1918” University, Alba Iulia (private university) - The Faculty of History and Philology

2. Sapientia Hungarian University of Transylvania (private university, specific statute) - Faculty of Technical and Human Sciences, Târgu-Mureş.

In the following, we present the most relevant data regarding the aims and curricula of the departments that organize BA programmes to train translators and interpreters. Most of the information is based on the documents and texts published on the websites of the different faculties and departments. Our analysis includes only BA programmes because - as presented above - there is no need to hold an MA degree to become a sworn translator and interpreter in Romania. We also provide a short presentation of the only MA programme in translation and interpreting that offers training in the Hungarian language.

\subsubsection{Departments of Applied Modern Languages}

3.1.1.1. Babeş-Bolyai University, Cluj-Napoca - Faculty of Letters (Department of Applied Modern Languages)

The department was established in 1991. Its main scopes are connected to the field of study with the same name and are defined by several specific features: 
it is multilingual, multidisciplinary and is built on its own language policy, in accordance with the fundamental principles of the AILEA Charter (Chart Internationale des Langues Étrangères Appliquées). It offers a course in at least two languages (both at an equal, highly professional level); the subjects are taught mainly in one of the foreign languages and are associated with a broad package of applied disciplines in the field of study: Applied Informatics and Multimedia, Economics, Management, Marketing, Public Relations, Law, Accounting and International Relations.

The language regime is identical to the one adopted by all the universities training professional translators and interpreters: $\mathrm{A}=$ native language (in the case of Romanian lines of study, it is the Romanian language), B = English or French, C = English, French, German, Italian, Spanish, and Russian. Language D is optional and requires an intensive course of 6 semesters in a language other than English or language B or C. This specialization forms and develops higher-level skills in general and specialized translation, terminology, multilingual professional communication, linguistic and cultural mediation, applied informatics and multimedia, text editing and revision, economics, accounting, marketing, management, law, public relations, and international economic relations. Internship is required in partner companies, recruitment being based on the specific skills gained at the Department of Applied Modern Languages Post Graduation Diploma: General Translator, Specialist in Professional Multilingual Communication.

The BA programme offers 4 semesters of "initiation in simultaneous/consecutive translation"; however, based on the syllabi on the website, only two of them include actual interpreting training and practice. This is almost exclusively done within the MA programme of the department: European Masters in Conference Interpreting.

\subsubsection{Transilvania University of Braşov - The Faculty of Letters - (Department of Theoretical and Applied Linguistics)}

The website lists the following under the heading of competences to be developed by the programme: acquisition of linguistic structures of the two foreign languages included in the study programme; understanding of the grammatical system of the languages studied within the framework of the programme; acquisition of fundamental communication techniques specific to the languages involved in the programme; acquisition of the main theories regarding translation from a foreign language into the native language of the student, as well as the ability to communicate effectively in both foreign languages featured by the study programme.

The short description of the programme includes the following: the Applied Modern Languages study programme (French-English, German-English) is 
structured on three basic components: i) fundamental disciplines (contemporary modern language, terminology), ii) specialized disciplines (theory and practice of translation, French/English/German cultural studies, specialized language, communication strategies, business correspondence), iii) supplementary disciplines (general economy, applied informatics, European integration and community institutions, modern language). In the second year of study, the programme incorporates optional disciplines; students can also choose a pedagogical module that would support a teaching career. The description also presents career opportunities: graduates can find jobs as specialized consultants, secretaries, researchers, translators/interpreters, experts, civil servants, etc.

\subsubsection{The West University of Timişoara - Faculty of Letters, History and Theology}

The specialization in Applied Modern Languages within this faculty was established in 2005, and it prepares specialized translators. Graduates will have gained skills in the following languages: English, French, German, Spanish (advanced), and Russian, Serbian, and Croatian (intermediate), as well as Italian and Portuguese (as optional modern languages).

\subsubsection{4. "Vasile Goldiş" Western University of Arad - Faculty of Humanities, Political and Administrative Sciences}

According to the faculty website, the mission of the Modern Languages Department (MLD) at the "Vasile Goldiş" Western University of Arad is to provide - through the study programmes and services offered - the assimilation and in-depth study of foreign languages in a European context. Through its educational offer, the department focuses on the development of communicative abilities and skills, and provides courses in the theory and practice of translation, interpretation and, of course, culture and civilization. All these elements are designed to guide the students on their way to achieving personal and professional excellence. The programme offers three foreign languages: English, French, and German.

\subsubsection{5. "Lucian Blaga" University, Sibiu - Faculty of Letters and Arts}

The study programme offers English, French, and German both as majors and as minors; the students are required to choose two of them. The most important subjects include Linguistics; Translation theory, Anglophone literature and cultures, American studies, British cultural studies, Canadian studies, Reception of Anglo-American literature in the Romanian culture, Comparative cultural studies, Political theory, Translation studies and specialized languages, Cognitive 
and applied linguistics, Civilization and mass media, The theory of translation and interpreting, Informatics, and Database management.

3.1.1.6. Petru Maior University of Târgu-Mureş - Faculty of Sciences and Letters

The programme is structured around two foreign languages, English as major and French as minor. The major subjects included in the programme are linguistics and grammar and foreign language competences, language for special purposes and terminology, academic writing skills, culture and civilization, language registers of the working languages, translation strategies and their adequate application, oral and written mediation, documentation techniques, event organization, NGOs and the functioning of the civil sector. According to the website, after graduation, the graduates may become: event organizers, external referents, translators and interpreters, proofreaders, editors, and linguists.

\subsubsection{North University of Baia Mare - Faculty of Letters}

The disciplines of the programme include economic and administrative terminology (French, English, and German) as well as an optional pedagogical module. Graduates will be licensed in applied modern languages and will become specialists in economic and administrative terminology in French, English, and German. They will have the possibility to work as specialized translators in the mentioned language pairs and, if they graduate teaching seminars, may become English / French / German teachers in primary and secondary education.

\subsubsection{Tibiscus University of Timişoara}

When it first offered BA studies for applied modern languages and training of translators and interpreters, it did so at the Faculty of Journalism, Communication and Modern Languages, which was founded in 1991 as the Faculty of Journalism and Sociology. It has not organized entrance examinations for this specialization since $1^{\text {st }}$ of October 2013.

\subsubsection{Universities (Faculties/Departments) organizing BA studies to} train translators and interpreters under the name of Translation and Interpreting Studies

\subsubsection{1. "1 Decembrie 1918” University, Alba Iulia - Faculty of History and Philology}

Unfortunately, there is not much information regarding the programme on the official website of the university; however, the students are offered English and 
French and courses in the field of linguistics, culture, and applied informational technology.

\subsubsection{Sapientia Hungarian University of Transylvania - Faculty of Technical and Human Sciences, Târgu-Mureş}

The BA studies programme of Translation and interpreting studies was founded in 2008 and was accredited in November 2014. It is the only programme that offers translation and interpreting training in the Hungarian language in Romania. The programme is part of the human sciences training branch. There are 50 places available, 20 tuition free and 30 with tuition, with three possible combinations: English-Hungarian (30 places in total), German-Hungarian (10 places in total), and Romanian-Hungarian (10 places in total).

The objective of the specialization is to train professionals who will be able to undertake specialized translations and deliver services of interpretation in international and multi-language conferences. Students are trained to translate from a foreign language (English, German, and Romanian) into Hungarian in an appropriate manner (grammatically and stylistically adequate translations) and to translate from Hungarian into their working language. It must be observed that in this case Romanian is included in the group of foreign languages, and Hungarian is considered the native language of the students.

The disciplines taught include the following: Contemporary English Language, British and American Culture and Civilization, Contemporary Hungarian Language, Hungarian Culture and Civilization, Comparative Linguistics, Terminology, Textology, Public Relations and Communication, Translation Theory, Theory and Practice of Interpretation (4 semesters).

Graduates may find employment as: free-lance translators, official translators hired in public administration, advisors in PR departments of international companies, advisors in advertising companies, employees or free-lance service providers to editing companies and publishing houses.

\subsection{The only MA programme with Hungarian as a working language}

The Sapientia Hungarian University of Transylvania, Faculty of Economic and Human Sciences Miercurea Ciuc organizes a Master's programme with international character, its partner institution being the University of Debrecen. There are 12 tuition free places and 16 with tuition. The programme is called Translation and Interpreting, and the languages of training are Hungarian, English, and Romanian.

This MA programme is designed to train professionals to develop and successfully apply the knowledge acquired in the domain of translation and 
interpreting in the fields of business, media, tourism, diplomacy, and international relations, at grant agencies, local governments, institutions, and foundations. A very important aim (amongst others) is the development of students' attitudes and intercultural tolerance in order to nurture discrimination-free behaviour; to help them easily make correlations between different cultures and languages and to study and analyse them. The programme develops the students' writing and presentation skills; it introduces them to the multi-, trans-, and intercultural phenomena of liberal arts from the viewpoint of translation studies, enabling them to identify and analyse the intercultural relations and to optimize strategies of maintaining and expanding these developed relations.

After graduation, the graduates may become: translators and interpreters, spokespersons, proofreaders, editors, linguists, event organizers, cultural referents, and linguistic consultants. After the completion of an MA programme, students can continue their studies in graduate-PhD programmes.

\section{Conclusions}

The disciplines taught at these faculties/departments are broadly similar. Unfortunately, theory prevails over practice. The translator training process needs to focus on the future translators and interpreters, and should do so from the moment potential students decide to sit an entrance examination. The process should continue to develop and nurture the required qualities through to the beginning of their working lives, as they set up translation agencies or secure their first job. Furthermore, training should place special emphasis on finding and holding on to clients, and avoiding basic mistakes. Vital professional issues of costs, rates, deadlines, time to market, productivity, ethics, standards, qualification, certification, and professional recognition should also be dealt with. The developments that have led to ongoing changes in the profession and industry, such as CAT-tools, and the impact of industrialization, internationalization, and globalization should also be incorporated in the curricula. Language for specialized purposes is very often only an optional subject and this should also be addressed: without greater focus on LSP, translators/interpreters cannot succeed.

Except for the ones organized by the Sapientia University, none of the above presented programmes include Hungarian as a working language, and very few of them offer interpreting courses, these being almost exclusively taught at the MA level. This means that in very many cases graduates of BA programmes, regardless of having attended an applied modern languages or a translation and interpreting programme, and who become authorized by the Ministry of Justice, have scarce or no training in interpreting. This results in providing a poor-quality service, and as such undermines the wider recognition of the profession. As we 
have already mentioned, the profession is not very well defined, translation and interpreting skills are not differentiated; a lack of prestige can also be observed.

In order to highlight this, we have chosen from the list of Standard Occupational Classification the ones that are recommended by the above institutions for students graduating as specialists in Translation and Interpreting or in Applied Modern Languages: 43-0000 Office and Administrative Support Occupations: General and keyboard clerks, General office clerks, Secretaries (general), Keyboard operators; 25-4000 Librarians, Curators, and Archivists; 11-2031 Advertising, PR, other activities related to communication; 27-3091 Interpreters and Translators: Interpret oral or sign language, or translate written text from one language into another: Diplomatic Interpreter, Court Interpreter.

We wish to continue our study regarding the social status and professional training of Hungarian interpreters and translators in Romania with the help of an online survey and by interviews aimed mainly at identifying the difficulties they face in their profession. The aim is also to gather empirical data to support our hypothesis that there is a need to differentiate translators from interpreters in the Romanian context as well. Unfortunately, the current situation favours neither this nor the specialization of translators and interpreters in different specialized languages.

\section{References}

Chesterman, A. 2001. Proposal for a Hieronymic Oath. The Translator. Studies in Intercultural Communication 7(2): 139-154.

Gile, D. 2009. Basic concepts and models for interpreter and translator training. Amsterdam/Philadelphia: John Benjamins Publishing Company.

Greere, A. 2010. Translation in Romania: Steps towards recognition and professionalization. Meta: journal des traducteurs / Meta: Translators' Journal 55(4): 789-816.

Greere, A.-C. Tătaru. 2008. Training for the translation profession: What do Romanian university programmes have to offer? Studia Universitatis BabeşBolyai Philologia. LIII(3): 95-122.

Horváth, I. 2005. A romániai magyarok kétnyelvűsége: nyelvismeret, nyelvhasználat, nyelvi dominancia. Regionális összehasonlító elemzések. Erdélyi Társadalom 3(1): 171-198.

Kopczyński, A.-A. Kowaluk. 1997. Nature or nurture. Are conference interpreters born or made? In: R. Hickey-S. Puppel (eds), Language history and Linguistic modelling. A Festschrift for Jacek Fisiak on his $60^{\text {th }}$ birthday. Volume II. Berlin: Mouton de Gruyter, 2075-2084. 
Pöchhacker, F. 2004. Introducing interpreting studies. London-New York: Routledge.

Robin, E. 2013. Az explicitáció következményei és etikája. In: Klaudy, Kinga (ed.), Fordítás és tolmácsolás a harmadik évezred elején. Budapest: ELTE Eötvös Kiadó, Eötvös Loránd Tudományegyetem, 49-64.

Schäffner, Ch. 2004. Researching translation and interpreting. In: Schäffner, Christina (ed.), Translation research and interpreting research. Traditions, gaps and synergies. Clevedon: Multilingual Matters.

Válóczi, M. 2010. A tolmácsoláshoz szükséges képességek és a tolmács-személyiség alakulása napjainkban. Képességfejlesztés a Tolmácsolás-gyakorlat órán. In: BGF Tudományos Évkönyv 2010, 28-34. 